Martin Weimann

Ertragswert und Börsenwert 



\section{Martin Weimann}

\section{Ertragswert \\ und Börsenwert}

Empirische Daten zur Preisfindung beim Delisting 
Dr. Martin Weimann, Rechtsanwalt, Berlin

ISBN 978-3-11-062705-3

e-ISBN (PDF) 978-3-11-062923-1

e-ISBN (EPUB) 978-3-11-062714-5

Library of Congress Control Number: 2020936662

Bibliografische Information der Deutschen Nationalbibliothek

Die Deutsche Nationalbibliothek verzeichnet diese Publikation in der Deutschen Nationalbibliografie; detaillierte bibliografische Daten sind im Internet über http://dnb.dnb.de abrufbar.

(C) 2020 Walter de Gruyter GmbH, Berlin/Boston

Einbandabbildung: New York City / Alamy Stock Foto

Satz: jürgen ullrich typosatz, Nördlingen

Druck und Bindung: CPI books GmbH, Leck

www.degruyter.com 